\title{
Doubtful and dangerous
}

The question of succession in late Elizabethan England

\author{
EDITED BY \\ SUSAN DORAN AND \\ PAULINA KEWES
}




\section{Doubtful and dangerous}

\section{MANCHESTER 1824}

Manchester University Press 


\title{
Politics, culture and society in early modern Britain
}

\author{
General Editors \\ DR ALEXANDRA GAJDA \\ PROFESSOR ANTHONY MILTON \\ PROFESSOR PETER LAKE \\ DR JASON PEACEY
}

This important series publishes monographs that take a fresh and challenging look at the interactions between politics, culture and society in Britain between 1500 and the mid-eighteenth century. It counteracts the fragmentation of current historiography through encouraging a variety of approaches which attempt to redefine the political, social and cultural worlds, and to explore their interconnection in a flexible and creative fashion. All the volumes in the series question and transcend traditional interdisciplinary boundaries, such as those between political history and literary studies, social history and divinity, urban history and anthropology. They thus contribute to a broader understanding of crucial developments in early modern Britain.

Recently published in the series

Chaplains in early modern England: Patronage, literature and religion HUGH ADLINGTON, TOM LOCKWOOD and GILLIAN WRIGHT (eds)

The Cooke sisters: Education, piety and patronage in early modern England GEMMA ALLEN

Black Bartholomew's Day DAVID J. APPLEBY

Insular Christianity ROBERT ARMSTRONG and TADHG Ó HANNRACHAIN (eds)

Reading and politics in early modern England GEOFF BAKER

'No historie so meete' JAN BROADWAY

Republican learning JUSTIN CHAMPION

News and rumour in Jacobean England: Information, court politics and

diplomacy, 1618-25 DAVID COAST

This England PATRICK COLLINSON

Sir Robert Filmer (1588-1653) and the patriotic monarch CESARE CUTTICA

Brave community JOHN GURNEY

'Black Tom' ANDREW HOPPER

Impostures in early modern England: Representations and perceptions of fraudulent identities TOBIAS B. HUG

The politics of the public sphere in early modern England

PETER LAKE and STEVEN PINCUS (eds)

Henry Neville and English republican culture GABY MAHLBERG

Royalists and Royalism during the Interregnum JASON MCELLIGOTT and DAVID L. SMITH

Laudian and Royalist polemic in Stuart England ANTHONY MILTON

Full details of the series are available at www.manchesteruniversitypress.co.uk. 


\title{
Doubtful and dangerous
}

The question of succession

in late Elizabethan England

\author{
Edited by \\ SUSAN DORAN and PAULINA KEWES
}

\section{Manchester \\ University Press}

Manchester and New York

distributed exclusively in the USA by Palgrave Macmillan 
While copyright in the volume as a whole is vested in Manchester University Press, copyright in individual chapters belongs to their respective authors, and no chapter may be reproduced wholly or in part without the express permission in writing of both author and publisher.

Published by Manchester University Press

Oxford Road, Manchester Mi3 9NR, UK

and Room 400, I75 Fifth Avenue, New York, NY ıooio, USA

www.manchesteruniversitypress.co.uk

Distributed in the United States exclusively by

Palgrave Macmillan, I75 Fifth Avenue, New York,

NY IоoIo, USA

Distributed in Canada exclusively by

UBC Press, University of British Columbia, 2029 West Mall,

Vancouver, BC, Canada V6T iZ2

British Library Cataloguing-in-Publication Data

A catalogue record for this book is available from the British Library

Library of Congress Cataloging-in-Publication Data applied for

ISBN 978 ○ 7I90 86069 hardback

First published 20I4

The publisher has no responsibility for the persistence or accuracy of URLs for any external or third-party internet websites referred to in this book, and does not guarantee that any content on such websites is, or will remain, accurate or appropriate.

Typeset in Scala with Pastonchi display

by Special Edition Pre-Press Services 